\title{
Analysis of the Impact of Local Government Competition on Regional Economic Growth
}

\author{
Zifan Yang ${ }^{1, \text { a }}$ \\ ${ }^{1}$ Tianjin University of Finance and Economics Pearl River College, Tianjin, 301811 \\ a email: yangzifan2001@126.com
}

\begin{abstract}
Keywords: Local Government Competition; Economic Growth; Market Competition; Macro-Control; Panel Data Model
\end{abstract}

\begin{abstract}
Based on the economic data of 31 provinces, this paper analyzes the impact mechanism of local government competition on the quality of economic growth in Chinese high-speed economic growth for more than 30 years from the perspective of economic growth, and selects the panel data model for empirical analysis. The results show that the competition of investment decision-making promotes the economic growth and has a negative impact on the ecological environment. Tax competition promotes economic growth and structural change, but it affects the welfare change and result distribution to a certain extent. There is positive relationship between promotion competition and economic growth. The local economic growth; local officials in the face of the same political competition and the economic growth of U-shaped non-linear response has local government financial services to promote economic growth.
\end{abstract}

\section{Introduction}

Chinese economy in the high-speed growth at the same time, there are worrying places. Its concerns exist in the following two aspects: First, Chinese economy does not consider the quality of economic growth, the main source of growth is the "three high and one low" (ie, high pollution, high energy consumption, high consumption, low efficiency) products, the quality of economic growth is low. Second, the "miracle of Chinese economic growth" is due to Chinese unique development path and the special relationship between government and enterprises determined. Among them, the competition of local governments is the main determinant of "Chinese economic growth miracle". Zhang Jun, Fu Yong et al. (2006) argue that it is the full competition between local governments and the economic growth of the region. Chen Benliang and Chen Wanling (2000) from the side of the study pointed out that the regional economic growth by the local government in the financial, tax and investment and other market competition.

The academic community has done a lot of research on the relationship between local government competition and economic growth, but the research perspective and depth can continue. This paper analyzes the impact of local government competition on investment competition, financial competition, tax competition, financial service competition, infrastructure construction competition, system competition and promotion competition on the quality of economic growth, and selects the panel data model Analyze provincial and regional analysis of the impact of local government competition on various indicators of economic growth.

\section{The Impact of Factors Analysis and Assumptions}

In order to realize the rapid economic growth, the local government is intensifying its competition. The main purpose of the local government is to promote the ability of attracting foreign investment in the region, aiming at the flow of resources outside its own region, and affecting the economic growth through the allocation of resources. In the blind investment, many "three high and one low" enterprises have also been introduced, although the promotion of regional economic growth, but caused the environmental pollution destroyed the regional ecological environment.

Scholars have made a detailed level of financial competition: the positive type, the government actively promote the system reform and encourage the existing technology innovation, for the 
economic growth of investment has been accumulated and improve the regional investment and development environment, attracting regional resources, promote Regional economic growth; conservative, the reform of the government system is not enough, the existing technological innovation is limited, do not attract foreign resources outside the region, the production of local enterprise products rely on government protection; negative competition, the Government to maintain the existing system and technology, Do not attract foreign resources outside the region, the production of local enterprise products rely entirely on government protection, the formation of local barriers. After the two local government competition is intensified, there is no order, its competition hindered the regional industrial economic restructuring and industrial transfer, industrial duplication of investment and construction caused a waste of resources, industrial scale effect is difficult to form, mutual block market protection regional economy, There is no effective collaboration between regions.

Chinese tax law has different tax preferential policies for different regions, so that local governments have a lot of room for tax competition, which can promote the economic growth, but the gap between the different regions is very big. The economically underdeveloped areas can improve the investment environment and attract the resources outside the region, which is of great significance to the regional economic development. However, the economic development of economically developed areas has a small impact. After years of development, economically developed areas have formed suitable industries for their own development Chain and a strong industrial scale, its implementation of a certain tax incentives have been unable to form an incentive for scientific and technological progress. Tax competition, while attracting foreign capital inflows and preventing the outflow of factors of production, has promoted regional economic growth, but has not played a role in redistribution of wealth.

Chinese political system is centralized under the appropriate local economic decentralization, the promotion of their own standards and institutional factors determine the official promotion space. The political competition between local officials has significantly stimulated local economic growth. Under the same political competition and political incentives, there are differences in the contribution of officials' competition in different regions to economic growth. Competition in eastern provinces can effectively promote economic growth, The effect of the central province is relatively weak, the effect of the western provinces is significantly lower than the eastern central region, which has a certain degree of damage to the enthusiasm of officials.

Hypothesis 4: Local officials promote competition to promote regional economic growth.

Hypothesis 5: Local officials face the same political competition and political incentives, the economic growth of U-shaped non-linear response.

Finance is the main service force and driving force of the real economy development. If the region has a relatively perfect financial services system, the development of the real economy can broaden the channels of financing funds to increase the mobility of enterprise development, to avoid the development of enterprises due to financial problems caused by bankruptcy situation.

Finance is the main service force and driving force of the real economy development. Financial service competition can continuously improve the local financial service system, improve the financial service system can reduce the cost of information and transactions, social idle funds into investment, and through the screening mechanism to optimize the efficiency of social investment. The development of regional finance will affect the savings rate, the ratio of investment conversion, the impact of social investment decision-making, affecting the allocation of social resources and thus affect technological innovation, thus affecting the region's long-term economic growth rate.

\section{The Impact of Local Government Competition on the Quality of Economic Growth based on Provincial Panel Data}

Because this paper measures the impact of local government competition on economic growth, and because the variable economic growth quality is not just a variable, this paper chooses the panel data model to suit the research needs. The basic form of the panel model is as follows:

According to the summary of the literature, the government investment decision-making, the 
selection of indicators for the actual use of foreign investment in the provinces the amount of growth rate, said FDI; local government financial competition, select the target for the local government budget expenditure, with FEB; local government tax Competition, select the local government's tax revenue growth rate as an indicator, with Tax; local government financial services competition, select the target for the local government loans as the proportion of GDP, with finance; infrastructure construction competition, with Infru said; Competition, the selection of indicators for the preferential policy index, with Institu said; promotion of competition, select the indicators for the provincial party secretary, governor of the promotion of dummy variables to measure, with Promo said.

Economic growth structure changes, select the ratio of the secondary industry and the tertiary industry, used to P said; economic growth rate of economic growth rate, with DGDP to express; welfare changes and the results of the allocation of per capita GDP, with PGDP to represent; The use of the main selection of resource allocation efficiency, with lntfp said; ecological environment selected per million GDP consumption of unit CO2, with Pe said.

The data mainly come from "China Statistical Yearbook", "China Financial Statistical Yearbook" and "China Environmental Statistical Yearbook". In particular, the data on the city of Chongqing, because the data does not have coherence, we are in the analysis of the merger into Sichuan Province.

Unit root test

In order to prevent the pseudo-regression of the panel model, we first perform the unit root test on all the time series data. We choose the ADF unit root test method to carry out the unit root test on the panel data. The test results are as follows:

Table 1 Unit root test for panel model data

\begin{tabular}{|l|l|l|l|l|}
\hline & ADF & P & obs & $\begin{array}{l}\text { Whether there is } \\
\text { a unit root }\end{array}$ \\
\hline Raw data & -116.939 & 0.0349 & 207 & Y \\
\hline Lag one period & -45.445 & 0.0140 & 207 & Y \\
\hline Lag two periods & 104.792 & 0.0000 & 207 & N \\
\hline
\end{tabular}

Note: This data is based on the Eviews test summary

From the above test, we can see that the original data and the first order lag panel data is not smooth, there is a unit root exists, but when all the panel data in the second order lag ADF = $104.792(\mathrm{p}=0.0000)$, visible lag two After the data is stable, it can be calculated as a panel data model.

F test and Hausman test

The panel data model is divided into mixed effect model, fixed effect model and stochastic effect model. Therefore, we must first determine whether it is a fixed effect model or a hybrid effect model, and judge the fixed effect and the mixed effect model with F test.

$$
\begin{aligned}
& F=\frac{\text { sse }_{r}-s s e_{u} / n-1}{s s e_{u} / n t-n-1}=\frac{(50.97442-0.399102) / 8-1}{0.399102 / 80-8-1}=1285.33 \\
& F=1285.33>F_{0.05}(106.99)=12.83
\end{aligned}
$$

Since the free variable of the model is assumed to be a random variable, it is necessary to test whether the model is an individual fixed effect model or an individual random effect model. The Hausman test is used to test the individual fixed effect model and the individual random effect model.

Hausman test: Hausman $=106.994>\chi_{0.05}^{2}(1)=3.8$

Local government competition will have an impact in a region, according to the provincial or clustering results analysis will ignore the relationship between the region, this paper in accordance with the geographical position, the provinces are divided into six regions, analysis of regional differences, Better explain the impact of local government competition on the quality of economic growth. 
The estimated results between the individual indicators are shown in Table 2 -6 below.

Table 2: Impact of local government investment decision on economic growth

\begin{tabular}{|l|c|c|c|c|c|c|}
\hline P & Municipalities & East coast & $\begin{array}{l}\text { Northeast } \\
\text { provinces }\end{array}$ & $\begin{array}{l}\text { Central } \\
\text { Region }\end{array}$ & Western Region & $\begin{array}{l}\text { Southwest } \\
\text { Region }\end{array}$ \\
\hline FDI & $\begin{array}{c}0.4949^{* * *} \\
(1.0044)\end{array}$ & $\begin{array}{c}0.2843^{* *} \\
(5.2345)\end{array}$ & $\begin{array}{c}0.5950^{* * *} \\
(9.0031)\end{array}$ & $\begin{array}{c}0.6982^{* * *} \\
(9.9987)\end{array}$ & $\begin{array}{c}0.3645^{*} \\
(12.0011)\end{array}$ & $\begin{array}{c}0.7421^{* *} \\
(10.2273)\end{array}$ \\
\hline FEB & $0.2386^{* *}$ & $\begin{array}{l}0.3185^{* *} \\
(1.9030)\end{array}$ & $\begin{array}{c}0.7843^{* *} \\
(8.9347)\end{array}$ & $\begin{array}{c}0.6466^{* *} \\
(10.1528)\end{array}$ & $\begin{array}{c}0.6443^{* *} \\
(11.3134)\end{array}$ & $0.6894^{* *}$ \\
& $0.3857^{* * *}$ & $0.2589^{* *}$ & $0.6534^{* * *}$ & $0.7781^{* * *}$ & $0.3311^{*}$ & $0.6990^{* *}$ \\
\hline Tax & $(1.0028)$ & $(5.5565)$ & $(8.8541)$ & $(10.4568)$ & $(11.6233)$ & $(12.0054)$ \\
\hline Finance & $0.4411^{* *}$ & $0.3221^{* *}$ & $0.5650^{* *}$ & $0.6321^{* *}$ & $0.6886^{* *}$ & $0.6118^{* *}$ \\
& $(1.7027)$ & $(5.4612)$ & $(8.0349)$ & $(11.1728)$ & $(12.0014)$ & $(11.0184)$ \\
\hline Infru & $0.3259^{* * *}$ & $0.3843^{* *}$ & $0.49164^{* * *}$ & $0.7282^{* * *}$ & $0.4051^{*}$ & $0.6631^{* *}$ \\
& $(1.8975)$ & $(5.5502)$ & $(5.6319)$ & $(10.6987)$ & $(10.2590)$ & $(11.1219)$ \\
\hline Institu & $0.3379^{* *}$ & $0.3781^{* *}$ & $0.6822^{* *}$ & $0.7066^{* *}$ & $0.6928^{* *}$ & $0.6261^{* *}$ \\
& $(1.630)$ & $(6.1613)$ & $(9.1335)$ & $(11.1527)$ & $(10.3130)$ & $(10.6093)$ \\
\hline Promo & $-0.1040^{* *}$ & $-0.3456^{*}$ & $-0.4573^{* * *}$ & $-0.5321^{* * *}$ & $-0.4011^{* *}$ & $-0.2009^{* *}$ \\
& $(1.5847)$ & $(7.0023)$ & $(10.0028)$ & $(11.1832)$ & $(10.8763)$ & $(13.0041)$ \\
\hline
\end{tabular}

Table3: Impact of local government tax competition on economic growth

\begin{tabular}{|l|c|c|c|c|c|c|}
\hline PGDP & Municipalities & East coast & $\begin{array}{l}\text { Northeast } \\
\text { provinces }\end{array}$ & $\begin{array}{l}\text { Central } \\
\text { Region }\end{array}$ & Western Region & $\begin{array}{l}\text { Southwest } \\
\text { Region }\end{array}$ \\
\hline FDI & $0.2791^{* * *}$ & $\begin{array}{l}0.4845^{* *} \\
(2.0150)\end{array}$ & $\begin{array}{l}0.6939^{* * *} \\
(10.2138)\end{array}$ & $\begin{array}{c}0.7080^{* * *} \\
(9.5621)\end{array}$ & $\begin{array}{c}0.5652^{*} \\
(18.7438)\end{array}$ & $0.5418^{* *}$ \\
& $0.2394^{* *}$ & $0.3185^{* *}$ & $0.7834^{* *}$ & $0.6466^{* *}$ & $0.6441^{* *}$ & $0.6880^{* *}$ \\
$(11.3133)$ & $(11.6197)$ \\
\hline FEB & $(1.9037)$ & $(5.0612)$ & $(8.9331)$ & $(10.1528)$ & $-0.151)$ \\
& $-0.8980^{* * *}$ & $-0.5811^{* *}$ & $-0.3950^{* * *}$ & $-0.3917^{* * *}$ & $-0.7655^{*}$ & $-0.5480^{* *}$ \\
Tax & $(2.3661)$ & $(5.0023)$ & $(9.9839)$ & $(10.8645)$ & $(14.1026)$ & $(19.2133)$ \\
\hline Finance & $0.2391^{* *}$ & $0.3185^{* *}$ & $0.7840^{* *}$ & $0.6466^{* *}$ & $0.6441^{* *}$ & $0.6876^{* *}$ \\
& $(1.9032)$ & $(5.0612)$ & $(8.9348)$ & $(10.1528)$ & $(11.3134)$ & $(11.6198)$ \\
\hline Infru & $0.4971^{* * *}$ & $0.2843^{* *}$ & $0.5950^{* * *}$ & $0.6982^{* * *}$ & $0.3650^{*}$ & $0.7423^{* *}$ \\
& $(3.5423)$ & $(6.3987)$ & $(7.3391)$ & $(14.5321)$ & $(16.3461)$ & $(17.3871)$ \\
\hline Institu & $0.2397^{* *}$ & $0.3185^{* *}$ & $0.7841^{* * *}$ & $0.6466^{* *}$ & $0.6440^{* *}$ & $0.6881^{* *}$ \\
& $(1.9038)$ & $(5.0612)$ & $(8.9345)$ & $(10.1528)$ & $(11.3130)$ & $(19.3231)$ \\
\hline Promo & $0.3571^{* *}$ & $0.2652^{* *}$ & $0.1250^{* * *}$ & $0.1321^{*}$ & $0.1211^{*}$ & $0.1145^{* *}$ \\
& $(5.3993)$ & $(8.6651)$ & $(6.5331)$ & $(13.5687)$ & $(15.3221)$ & $(18.6449)$ \\
\hline
\end{tabular}

Table4: Impact of local government fiscal competition on economic growth

\begin{tabular}{|c|c|c|c|c|c|c|}
\hline DGDP & Municipalities & East coast & $\begin{array}{l}\text { Northeast } \\
\text { provinces }\end{array}$ & $\begin{array}{l}\text { Central } \\
\text { Region }\end{array}$ & Western Region & $\begin{array}{l}\text { Southwest } \\
\text { Region }\end{array}$ \\
\hline FDI & $\begin{array}{c}0.3662 * * * \\
(1.4052)\end{array}$ & $\begin{array}{l}0.2347 * * \\
(6.2247)\end{array}$ & $\begin{array}{l}0.6635^{* * *} \\
(10.1013)\end{array}$ & $\begin{array}{l}0.8911^{* * *} \\
(10.1129)\end{array}$ & $\begin{array}{c}0.5657^{*} \\
(11.8102)\end{array}$ & $\begin{array}{c}0.6422 * * \\
(11.3281)\end{array}$ \\
\hline FEB & $\begin{array}{l}0.4391 * * \\
(1.9031)\end{array}$ & $\begin{array}{l}0.6182 * * \\
(5.0612)\end{array}$ & $\begin{array}{l}0.7816^{* *} \\
(8.9346)\end{array}$ & $\begin{array}{c}0.5467 * * \\
(10.1528)\end{array}$ & $\begin{array}{c}0.6656^{* *} \\
(11.3141)\end{array}$ & $\begin{array}{c}0.7028 * * \\
(11.6198)\end{array}$ \\
\hline Tax & $\begin{array}{c}0.5863 * * * \\
(1.0034)\end{array}$ & $\begin{array}{l}0.2981^{* *} \\
(5.5565) \\
\end{array}$ & $\begin{array}{c}0.6539 * * * \\
(8.8555) \\
\end{array}$ & $\begin{array}{l}0.7711 * * * \\
(10.4568) \\
\end{array}$ & $\begin{array}{c}0.4391^{*} \\
(11.6264) \\
\end{array}$ & $\begin{array}{c}0.6987 * * \\
(12.0031) \\
\end{array}$ \\
\hline Finance & $\begin{array}{l}0.7433^{* *} \\
(1.7035)\end{array}$ & $\begin{array}{l}0.2229 * * \\
(5.4612) \\
\end{array}$ & $\begin{array}{l}0.4628^{* *} \\
(8.0346)\end{array}$ & $\begin{array}{c}0.6321^{* *} \\
(11.1728) \\
\end{array}$ & $\begin{array}{c}0.7898 * * \\
(12.0031) \\
\end{array}$ & $\begin{array}{c}0.6126^{* *} \\
(11.0189) \\
\end{array}$ \\
\hline Infru & $\begin{array}{c}0.6265^{* * * *} \\
(1.8982) \\
\end{array}$ & $\begin{array}{l}0.2843^{* *} \\
(5.5502) \\
\end{array}$ & $\begin{array}{c}0.4210 * * * \\
(5.6317) \\
\end{array}$ & $\begin{array}{l}0.7282 * * * \\
(10.6987) \\
\end{array}$ & $\begin{array}{c}0.5056^{*} \\
(10.2588) \\
\end{array}$ & $\begin{array}{c}0.6621^{* *} \\
(11.1220) \\
\end{array}$ \\
\hline Institu & $\begin{array}{c}0.5390^{* *} \\
(1.640)\end{array}$ & $\begin{array}{l}0.4711^{* *} \\
(6.1613) \\
\end{array}$ & $\begin{array}{l}0.6813^{* *} \\
(9.1349)\end{array}$ & $\begin{array}{c}0.7066^{* *} \\
(11.1527)\end{array}$ & $\begin{array}{c}0.6940 * * \\
(10.3132)\end{array}$ & $\begin{array}{c}0.6269 * * \\
(10.6188)\end{array}$ \\
\hline Promo & $\begin{array}{c}0.4041 * \\
(1.5852) \\
\end{array}$ & $\begin{array}{c}0.5459 * \\
(7.0023) \\
\end{array}$ & $\begin{array}{l}0.4589 * * * \\
(10.0041)\end{array}$ & $\begin{array}{l}0.5621 * * * \\
(11.1832)\end{array}$ & $\begin{array}{c}0.4885^{* *} \\
(10.8756) \\
\end{array}$ & $\begin{array}{c}0.3921 * * \\
(13.0016) \\
\end{array}$ \\
\hline
\end{tabular}


Table5: Impact of local government promote competition on economic growth

\begin{tabular}{|l|c|c|c|c|c|c|}
\hline Lntfp & Municipalities & East coast & $\begin{array}{l}\text { Northeast } \\
\text { provinces }\end{array}$ & $\begin{array}{l}\text { Central } \\
\text { Region }\end{array}$ & Western Region & $\begin{array}{l}\text { Southwest } \\
\text { Region }\end{array}$ \\
\hline FDI & $\begin{array}{c}0.4960^{* * *} \\
(1.010)\end{array}$ & $\begin{array}{c}0.2843^{* *} \\
(5.023)\end{array}$ & $\begin{array}{c}0.5932^{* * *} \\
(7.7776)\end{array}$ & $\begin{array}{c}0.6982^{* * *} \\
(11.0474)\end{array}$ & $\begin{array}{c}0.3656^{*} \\
(10.2461)\end{array}$ & $\begin{array}{c}0.7421^{* *} \\
(12.0018)\end{array}$ \\
\hline FEB & $0.2391^{* *}$ & $\begin{array}{c}0.3185^{* *} \\
(5.0612)\end{array}$ & $\begin{array}{c}0.7838^{* *} \\
(8.9345)\end{array}$ & $\begin{array}{c}0.6466^{* *} \\
(10.1528)\end{array}$ & $\begin{array}{c}0.6453^{* *} \\
(11.3224)\end{array}$ & $0.6880^{* *}$ \\
& $(1.9031)$ & $0.2843^{* *}$ & $0.5939^{* * *}$ & $0.6982^{* * *}$ & $0.3654^{*}$ & $0.7419^{* *}$ \\
\hline Tax & $0.4957^{* * *}$ & $(7.003)$ & $(7.0078)$ & $(14.2107)$ & $(13.2501)$ & $(10.5869)$ \\
\hline Finance & $(2.2181)$ & $0.3185^{* *}$ & $0.7842^{* *}$ & $0.6466^{* *}$ & $0.6440^{* *}$ & $0.6880^{* *}$ \\
& $0.2392^{* *}$ & $(5.0612)$ & $(8.9348)$ & $(10.1528)$ & $(11.3134)$ & $(11.6200)$ \\
\hline Infru & $(1.9048)$ & $\left.0.2843^{* *}\right)$ & $0.5943^{* * *}$ & $0.6982^{* * *}$ & $0.3652^{*}$ & $0.7413^{* *}$ \\
& $0.4960^{* * *}$ & $(6.3874)$ & $(9.3869)$ & $(15.2310)$ & $(1.0051)$ & $(9.9981)$ \\
\hline Institu & $(2.8552)$ & $0.3185^{* *}$ & $0.7844^{* *}$ & $0.6466^{* *}$ & $0.6441^{* *}$ & $0.6880^{* *}$ \\
& $\left(1.4386^{* *}\right.$ & $(8.9347)$ & $(10.1528)$ & $(11.3132)$ & $(11.6193)$ \\
\hline Promo & $0.2591^{* * *}$ & $0.6311^{* *}$ & $0.8739^{*}$ & $0.4213^{*}$ & $0.5621^{* *}$ & $0.8874^{* *}$ \\
& $(1.8660)$ & $(4.2351)$ & $(9.3680)$ & $(10.0001)$ & $(9.9986)$ & $(10.0074)$ \\
\hline
\end{tabular}

Table6: Impact of government financial service competition on economic growth

\begin{tabular}{|l|c|c|c|c|c|c|}
\hline Pe & Municipalities & East coast & $\begin{array}{l}\text { Northeast } \\
\text { provinces }\end{array}$ & $\begin{array}{l}\text { Central } \\
\text { Region }\end{array}$ & Western Region & $\begin{array}{l}\text { Southwest } \\
\text { Region }\end{array}$ \\
\hline FDI & $-0.4481^{* * *}$ & $\begin{array}{c}-0.3881^{* *} \\
(5.5587)\end{array}$ & $\begin{array}{c}-0.5866^{* * *} \\
(9.24356)\end{array}$ & $\begin{array}{c}-0.5992^{* * *} \\
(11.0021)\end{array}$ & $\begin{array}{c}-0.4231^{*} \\
(12.3607)\end{array}$ & $\begin{array}{c}-0.5921^{* *} \\
(11.5900)\end{array}$ \\
\hline FEB & $-0.2389^{* *}$ & $-0.3185^{* *}$ & $-0.7854^{* *}$ & $-0.6466^{* *}$ & $-0.6251^{* *}$ & $-0.6976^{* *}$ \\
& $(1.9019)$ & $(5.0612)$ & $(8.9356)$ & $(10.1528)$ & $(11.3131)$ & $(11.7180)$ \\
\hline Tax & $-0.4971^{* * *}$ & $-0.2743^{* *}$ & $-0.5937^{* * *}$ & $-0.6932^{* * *}$ & $-0.3621^{*}$ & $-0.7316^{* *}$ \\
& $(1.6560)$ & $(5.6974)$ & $(8.9948)$ & $(10.9875)$ & $(13.0023)$ & $(11.5630)$ \\
\hline Finance & $0.2389^{* *}$ & $-0.3555^{* *}$ & $-0.7834^{* *}$ & $-0.6461^{* *}$ & $-0.6420^{* *}$ & $-0.6481^{* *}$ \\
& $(1.9012)$ & $(5.3612)$ & $(8.4345)$ & $(10.1528)$ & $(11.8141)$ & $(11.6200)$ \\
\hline Infru & $-0.4971^{* * *}$ & $-0.2363^{* *}$ & $-0.5896^{* * *}$ & $-0.6912^{* * *}$ & $-0.3651^{*}$ & $-0.7920^{* *}$ \\
& $(1.3274)$ & $(5.0012)$ & $(8.0247)$ & $(11.0030)$ & $(10.9990)$ & $(10.9984)$ \\
\hline Institu & $0.0019^{* *}$ & $0.0125^{* *}$ & $0.0150^{* *}$ & $0.0216^{* *}$ & $0.0488^{* *}$ & $0.0841^{* *}$ \\
& $(1.6954)$ & $(5.9870)$ & $(8.7376)$ & $(10.7524)$ & $(12.3143)$ & $(11.7200)$ \\
\hline Promo & $0.0089^{* * *}$ & $0.0123^{* *}$ & $0.0079^{*}$ & $0.0681^{* * *}$ & $0.0013^{*}$ & $0.0046^{* *}$ \\
& $(1.0257)$ & $(5.087)$ & $(9.0032)$ & $(10.6982)$ & $(12.0043)$ & $(13.5690)$ \\
\hline
\end{tabular}

First, the local government investment decision-making competition on the 31 provinces of the overall economic growth has played a catalytic role in the ecological environment had a negative impact, but the size of the region varies, the eastern coastal Second, the local government financial competition on the eastern coastal areas, municipality and the central region of the economic growth effect is poor, the western region, the southwest region and the three provinces have a relatively obvious difference between the three provinces and the southwest region, Third, the tax competition to promote economic growth and structural changes, the eastern coastal areas, municipalities, the effect is significantly lower than the central and western regions, to some extent affect the welfare changes and results distribution; Fourth, local officials to promote competition to promote Economic growth; Fifth, local officials in the face of the same political competition and political incentives, the economic growth of U-shaped non-linear response; Sixth, local government financial services competition to promote the quality of economic growth.

\section{Conclusion}

In view of the theoretical and empirical structural equation model analysis, the local government investment decision-making competition has a positive effect on the quality of economic growth and has a negative effect on the development of the ecological environment. The local government's financial competition has a positive effect on the economic growth of the eastern and central regions The impact of the policy is not very significant, the relative significant inhibition of the western; tax competition to promote economic growth and structural changes; local officials to promote competition to promote economic growth; local officials in the face of the same political competition and political incentives, Its economic growth presents a U-shaped non-linear response; local government financial services competition to promote economic growth. By analyzing the impact of local government competition on economic growth, it can provide theoretical planning basis and practical guidance significance for the development of new urbanization and the 
promotion of Chinese economic development.

\section{Acknowledgements}

Tianjin Social Science Project 2015 "Fiscal policy selection and optimization research based on the promotion of employment" (TJYY15-019)

\section{References}

[1] Zhou industry, Feng Xingyuan, Zhao Jianyi. Local government competition and market order reconstruction [J]. Chinese Journal of Social Sciences, 2014 (1): 56-65.

[2] Jiang Manyuan. Regional sustainable development in the local government competition problem [M]. Beijing: China Agricultural Publishing House, 2007.

[3] Liu Qiang, Tan Chenglin. Local government competition and regional institutional innovation: a system analysis perspective [J]. Published, 2009 (6): 46-49.

[4] Liu Yaping. Contemporary Chinese local government competition [M]. Beijing: Social Science Literature Publishing House, 2007.

[5] Xie Xiaobo. Local government competition and regional economic coordinated development Chinese transition economy as the background of the analysis [R]. Zhejiang University doctoral dissertation, 2006 